\title{
Power, politics and policing: how the pandemic has highlighted fractures and fault lines in our society
}

\author{
Rod Jarman QPM OStJ FICPEM FCMI ${ }^{1}$
}

\begin{abstract}
This paper considers the issues of policing in the pandemic and describes the relationship between the use of power within society with political systems and the ways in which police outcomes are achieved. The year 2020 created a unique opportunity to reflect upon the way policing systems are structured and how this affects the whole of society, and this paper looks at how the dynamics of race and oppression played into this. The risk for policing is that it fails to make use of its community assets to engage effectively with the community, and becomes reliant on the use of blunt tools and force. This paper concludes that the challenge for police leadership is defined by how society (and their forces) manage issues of fairness to reduce the amount of force and violence in society and ensure the state is there to protect all citizens.
\end{abstract}

\section{Introduction}

In 1959 French and Raven analysed and codified sources of power. ${ }^{2}$ Since then, leadership gurus, organisational analysts and social scientists have applied and developed models, thinking about them from the perspective of individuals' access to power and the implications of its use. This past year has seen the fragility of human existence exposed through the virus, which we have come to know as COVID-19. This paper will explore the events from the perspective of the police and policing and ask what we have learnt about society and the inequalities which exist within it, and, most importantly, the opportunities for addressing these.

This paper will consider the events of the past year, how the pandemic affected the role of police, their legitimacy and performance, and how these factors connect with the renewed concern about police relationships with diverse communities. These will be considered through a wide initial context, followed by specific review of the impact of the pandemic on policing (looking at popularism and political leadership), pandemic (preparation and responsibilities) and policing in a time of crisis, and, finally, the implications for the future will be considered. It intends to highlight faultiness in policing and try to reinforce the debate on police community relationships.

The officers on the beat and the investigators responding to calls for assistance have been tested beyond reasonableness and have delivered incredible feats on behalf of us all, putting themselves at risk and, indeed, in many cases losing their lives to protect us. The factors identified here are not comments on the professional and selfless service provided day in and out, but are an analysis of why, at times, that is not enough for the complex society we live in.

\section{Policing the pandemic: politics, popularism and pandemic}

Political leadership and parties in many countries have recently seen a move away from wide general policies based upon a historic view of what a 'political party' stood for, instead campaigning on specific issues to gain support from a wider electorate based upon specific goals or issues. In the UK this was epitomised by the Brexit campaign and, in the US, 'making 
Vol. 8, No. 1, 100-113.

America great again.' This has brought new dynamics into how these democracies are led, which are also being felt in other places, such as France and Germany, where the growth of a vocal far right caucus is challenging the norm. These changes mean that once in power, politicians have strange coalitions which they need to manage, even after their driving goal has been achieved. The result is a greater focus on perceptions and campaigning than on the truth and resolution of underlying issues. In societies already dealing with cycles of change through different governments, this adds a further level of angst and uncertainty.

In the UK this has seen the government promote complex and continually changing messages. These include:

- A constant swing between there being nothing to worry about - the virus is not that bad and we need to get back into shops and business - to society being on the brink of a disaster of biblical proportions. This changing and confused communication has provided the space for those who have a single, clear, all be it incorrect, message (such as anti-vaxers) to flourish.

- Many government spokespeople promoting their own area, or even themselves, unable to clearly articulate government policy or the meaning of advice.

- Failures to comply with transgression to the advice and law when made by individuals closest to those in power. Indeed, not just ignoring their actions but actively supporting their decisions. The most flagrant example of this has been the Prime Minister's advisor driving across the country (when people were being told to put society first) and then explaining the car journey was necessary to test his eyesight to see if he was fit to drive. ${ }^{3}$

- The promotion of ethically questionable actions written into law as part of the Brexit negotiations, when the UK Government decided to unilaterally deviate from their own agreement with the EU.

- The weight placed on scientific advice fluctuating depending upon the political goal being chased - sometimes everything was about the science, at other times the science was selectively applied.

In the US, the campaign for the election of the new president started with a sitting president questioning the fairness and legality of the system. This set up a position where, when he lost the election, he reverted to as evidence of unfairness and corruption. This approach finally led to the attack on Congress (both the buildings and the occupants). The chilling video produced in the impeachment hearings of the president, showed the crowd attacking the building and actively searching out politicians to attack, underlines the implications from politicians' words. Here the crowd, and much of the country, have been moved to believe their constitution is not working and the process undemocratic. This releasing visceral emotion and anger against the system.

These issues of style and approach were not evident everywhere. In the UK, the leader of the SNP and the Scottish Assembly provided a measured and sustained message, evidenced and supported by a constantly evolving but accurate narrative. This narrative created a sense of calm resilience, a focus on doing the right thing for the country and a sense of purpose. One cannot but look at the carnage and mistrust that has been caused in the countries with men driving conversations to gain their own political ends and unwilling to consider others, when compared with that of the leaders of Scotland and New Zealand who have steadfastly and resolutely followed an effective approach, communicated clearly and built trust.

This political dynamic has a massive impact on policing, especially where the politicisation of the police has been driven under the narrative of increasing public scrutiny. In this world the expectations are that the police will follow the political lead, will change their role to fit in with the needs of the leaders and are seen by politicians as being responsible for the governance and control of the population. These are key changes that affect the police 
position in society, how they work and what they focus on - an issue that will be addressed later in this paper. The political leadership expect the police to create compliance with the law. This is reinforced with repeated discussions about the number of officers deployed, the budget invested and the number of tickets issued, as if these are outcomes rather than inputs in the complex world of crime control. Garland (2002) ${ }^{4}$ describes this at length and poses that decisions in policing become framed within two agendas, the internal one aimed at the core mission of the police (originating in Peel's principles) and the external political goals set to achieve short-term impact for a particular issue.

The outcome is a police service that is berated for being too keen to issue penalties and, at the same time, to soft, as they try and find a way through this complex nexus of priorities. This year has seen urgent new priorities introduced to save lives, with an underpinning message from government of urgency and importance. Repeatedly, however, when the police responded they were criticised for being too robust, and then when they moved to a significant model of engaging people, of not holding the right line. However, when people close to those in leadership (e.g., Cummings) broke the rules, the political elite stood next to them and said people need to do what they think is right.

It is an adage in policing that if both sides of an argument are criticising you, then you are close to doing things right. In this case, police leaders found themselves being criticised by those in political control for both sides. Whilst the issues of the pandemic made this more acute, these are problems which will not go away easily and will no doubt be repeated frequently. They expose a fault line in the system, which for years was addressed through the distancing of political control through the balance between local communities and central government - the tripartite system created by the Police Act 1964. The move to locally elected police and crime commissioners was intended to put greater power to the local community. However, with a centralised government with the real power, and with considerable influence over local politicians, what has developed is a network of local people who will either bow down to the centre or create local conflict for their own gains. This year we have seen PCCs do this, we have seen chief constables forced to resign ${ }^{5}$ and we have seen local police leaders being called in to support their 'political masters'.

This centralised approach reflects the popularist political agenda where those in 'power' need to be able to show what they have done (in terms of directing others) whilst keeping themselves removed from the complex decisions to be made. Being in power during the COVID-19 pandemic posed many complex problems that needed to be resolved. The solutions to these problems required a stable and resilient framework to shape and guide decision making. Legally, that framework was the Human Rights Act and the Civil Contingencies Act. What we have seen is little, if any, reference to the right to life and decisions framed by political rather than ethical processes. In other words, ensuring that as many people as possible with political sway are happy with an outcome, it looks like something has been achieved, and avoiding (or at least delaying) hard decisions to the latest possible moment.

There have been pseudo discussions about the risks to life if the economy cannot manage the crisis and the moral panic around the 'lost generation of children' whose education has been affected or who have not been safeguarded. ${ }^{6}$ Mark Carney, the outgoing governor of the Bank of England, in the 2020 Reith lecture discusses the balance between financial and human value. He was clear in the need to put human life first and how, from an economics and finance perspective, we must address the first and most critical risk (that of life over death) before we begin to consider the longer-term risks. ${ }^{7}$ The World Health Organization made it clear that this is the right approach, and yet several popularist leaders (including Johnson, Trump and Bolsonaro) have tried to balance the long-term potential risks and, in doing so, many tens, if not hundreds of thousands, of lives have been seen to be of less importance than the long-term economy of the state. Our young people have not 
Vol. 8, No. 1, 100-113.

been offered an alternative (a new and polished education system that delivers online with examinations fit for purpose), but have been bounced in and out of an often ill-equipped education system, which does not seem capable of moving into a new paradigm. Like the health service, generations of politicians have failed to invest adequately in our education system, so now, when it is at risk, the political imperative is getting back to the past rather than dealing with long-term problems that would allow us to work through the pandemic.

Against this backdrop of political angst, the country and the police were responding to the largest crisis in recent history. Whilst these comments focus on the UK, the same arguments apply to many places - the world was not ready for the pandemic. A pandemic has been the number 1 risk on the UKs resilience risk register for many years, with control measures of stockpiles of PPE and medicines supposedly meaning our 'world class' NHS would be able to cope. What became clear, almost immediately, is that years of underfunding meant that the primary responders (the NHS) were ill equipped, under resourced (with over 100,000 staff vacancies) and were already in crisis.

The fault lines here are several, systemic and reflect an over confidence in our capabilities:

- Firstly, a desire to cut costs - pressurising managers to focus on the here and now and not on preparing for what might happen. This could be described as a lack of balance between expenditure and need.

- Secondly, a belief that this was a medical problem. The NHS was the lead body but the main response was one of changing public behaviour - of social control to reduce infections - an area where the NHS did not have expertise or the resources to lead at a national level.

- Thirdly, the response became focused upon national initiatives and not upon the local forums where fast actions could be taken. The term crisis, and the thought about crisis management, was confused with the response to a major incident, where normality would be resumed. One year into this crisis, we have still not accepted that our old world is gone, that we must now live with new approaches to life and new constraints on how we live - that we are not in control and that nature will find new challenges for us.

- Finally, in some jingoistic post-imperial way, we believe we have the best health service, the best education system in the world and the best police force in the world. We certainly have dedicated and expert people working in under-resourced and often unfit premises achieving great outcomes. But our health service, education system and police do not produce the same results as others, and need either more resources or a rethink.

The desire to respond to this more as a major incident that will pass has put considerable strain on the front line and on families, and will have long-term repercussions. This is true for the police too, who have been on the front line, not just dealing with crime and compliance with COVID laws but have been filling holes in other services - driving ambulances, recovering dead bodies and looking out for the most vulnerable.

\section{Policing the pandemic: crime and social governance}

Whilst the professionalisation of policing in the UK is building a greater emphasis on evidence-based policing and crime reduction, the curriculum for officers focuses on two theoretical approaches, with crime a consequence of mobility. In these models the occurrence of crime is a direct result of the movement of those who commit crime amongst a landscape of crime opportunities. These approaches, referred to as routine activity theory and rationale choice theory, suggest that when the opportunity is low (either because of the lack of vulnerable targets, the lack of motivation of offenders or there being strong guardianship) and the 
disbenefits outweigh the possible gains, then crime is less likely. This approach was used to consider the impact of the controls on movement on crime. ${ }^{8}$ What was clear from this work was that whilst many crime types had an immediate and significant reduction, it was not true for all. In these cases, other models needed to be considered. However, as reported by the ONS, this was more of a fluctuation rather than a long-term change, with crime bouncing back immediately after the initial lockdown (Ross 2020). ${ }^{9}$ The report identifies that calls for the police increased and drug abuse went up, but it excluded the widely reported developing digital crime.

Online crimes of fraud and deception are poorly reported and, whilst there is significant evidence of large increases, there is a lack of information at this stage about what they tell us about the long-term. Clearer is the large growth in harmful practices, especially domestic abuse. This was reported in countries from Sweden, the UK and Ireland in Europe, to Peru, Australia and New Zealand. The immediate analysis was that if you are unable to leave your home then you are more vulnerable. This is compounded by reports of those who did escape being returned home by police, acting on lockdown rules, to be subjected to yet more violence (police from Sweden and the UK provided similar accounts).

As the pandemic and governments' responses unfolded, two clear and new dynamics were introduced as the structures, systems and behaviour of society was altered to address infection rates, and new crimes were introduced to address non-compliance. In hindsight these seem commonplace but, in March 2020, the introduction of a national lockdown, with people being paid to stay at home and only critical workers being allowed out of their homes, was a fundamental and historic blow to the freedoms expected within the UK and other countries. Police resources were reduced and officers were refocused to duties such as lockdown patrols (using hotspot methodologies designed to address property crimes) and providing support to healthcare.

The new crimes have created additional demands on police, and the added problem of being at the front end of the debate about legitimacy regarding the approach. New crimes are normally brought in following review and consideration, including Green Papers to identify opportunities and White Papers to consult on approaches for parliament to then review and improve. Once implemented, laws take many years to bed in, with case law dealing with the unintended consequences and problems. These laws have been implemented without these checks, balances and opportunities to adjust. In addition the use of fixed penalty notices, clearly intended to prevent additional burdens on Courts, has changed the balance from a presumption of innocence into the summary issuing of penalties up to 110,000 .

Government policy has been to make a case for people to comply with rules and laws, and to back this with the threat of significant financial penalties. Effectively they are applying rational choice theory, expecting people to balance the gains from complying, which are perceptions of doing good for others - the message being 'stay at home, protect the NHS and save lives') - with the consequences of non-compliance (possible significant fine). Figure 1 sets out the impact of the lockdown on mobility, which shows a significant impact in the first lockdown and then a reducing impact over time. This does not reflect a society staying at home with car journeys and footfall absent, but does reflect a significant change in behaviour.

The question is whether that change is sufficient and whether the right people are staying at home. If this is the right policy and if it is working, one could expect to see low levels of transmission. What is not known is what we would expect to see if there was no control and what would be seen if there was absolute control. The current scenario would then sit in the middle of those two, and the level of social interaction allowed would be governed by Article 1 of the Human Rights Act. The stated intention of the government is to keep the R number for the virus below 1 . Together these approaches are intended to control the proportion of the population affected. 
Vol. 8, No. 1, 100-113.
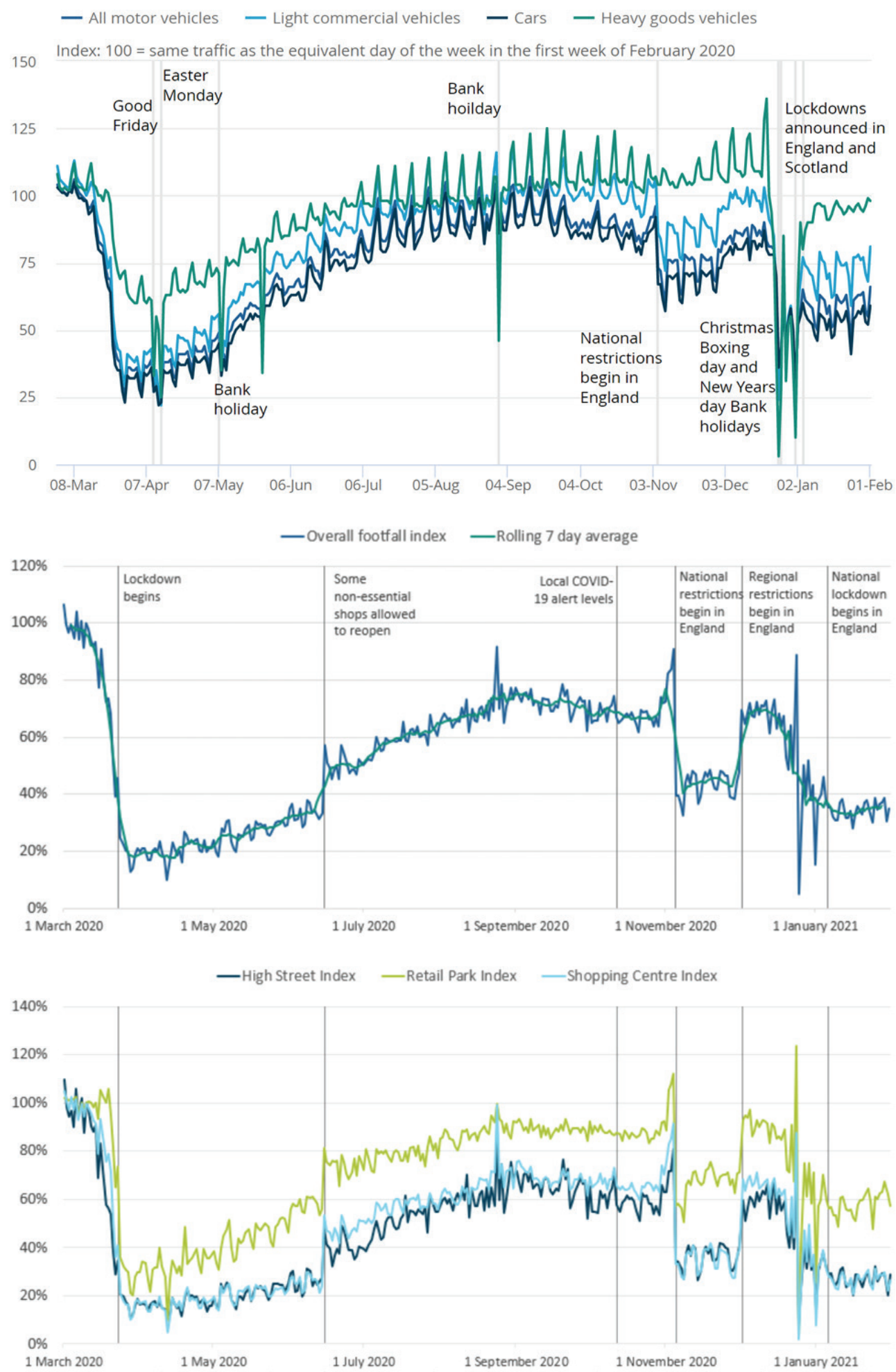

Figure 1 Graphs to show changes in the mobility of the public during the pandemic ${ }^{10}$ Source: Springboard and the Department for Business, Energy and Industrial Strategy

The graph in Figure 2 demonstrates how this approach is reflected in the infection rate. What is not yet analysed or presented is what greater compliance could have achieved. The data sets clearly show that deaths other than COVID are significantly down, so there is no evidence of displacement. 


\section{England}

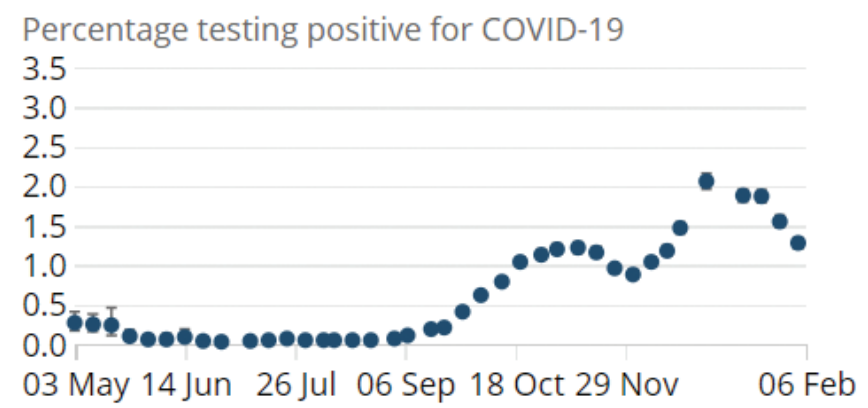

Figure 2 Graph to show infection rate in England 2020-2021

Other approaches to social control, such as the social influence conception of deterrence (Harcourt 1998), ${ }^{12}$ provides an alternative approach - where the relationships between perceptions of safety, perceptions of criminals being brought to justice and perceptions of orderliness establish what might influence actions, what gives them meaning and what normalises them in society. This model allows differential outcomes based upon community members perceptions. If you feel safe, then you will be more orderly. For this to occur individuals need to perceive criminality is being addressed. This year saw active encouragement by the government for people to travel and socially integrate (University students, Eat Out to Help Out, etc.), active support for those who failed to comply with the regulations (Cummings etc.) and a lack of consistent messaging, leaving the police to provide a balanced and sensible response in a chaotic world.

The balance of enforcement versus encouragement has meant the police seem to have maintained confidence, but there are significant risks if this is not quickly reversed or is seen as the way to deal with other offending. This will have an impact on staff morale and health and, over time, will leave the police open to criticism for the response they made.

\section{Policing the pandemic: the impact on officers}

The impact of COVID-19 on policing has varied greatly across the world. A recent analysis identified some disturbing variations and potential long-term issues for police officers. ${ }^{13}$ For instance, in Peru, over 530 officers have died from COVID-19, where in most other countries, whilst significant, the numbers are much less. This paper does not attempt to explain these differences but is more concerned with the impact such significant loss of life will have, both in Peru and to policing more generally. There, as in many countries, the police role has evolved into a wider healthcare provider role, with police having specific roles in the collection of infected cadavers and interaction with the families of those who are ill.

With a population of 32.5 million, and close to 42,00o deaths (John Hopkins University), ${ }^{14}$ Peru has been affected badly, however, less so than the UK or other European countries. Brigadier General Sergio Moyoli explained the causes as being: ${ }^{15}$

1. Poor healthcare for their officers. As a result, the police built, equipped and staffed a hospital solely for officers.

2. Lack of PPE and understanding of basic approaches to reduce the risk.

3. The significant interaction with the public in confrontations due to population movement. In April 2020, Collins (2020) ${ }^{16}$ reports the plight of the poor in Lima trying to flee the city and return to the country, and being stopped by the police enforcing lockdown laws. 
Vol. 8, No. 1, 100-113.

In the UK, the levels of death and serious illness of serving officers have thankfully been relatively much lower than this, but still horrendous to those affected. National coordination of the response under Operation Talla was led by the Chair of the National Police Chiefs Council (Assistant Commissioner Martin Hewitt). This operation consulted with forces and drove forces toward a coordinated response which led to action to manage those higher at risk with remote working, the introduction of new risk assessment processes to reduce interactions and the use of PPE were identified as some of the practices that may have led to better outcomes (Hewitt 2020). By the end of December, national systems to monitor and share resources between UK-based forces showed levels of concern but had not reached the $20 \%$ abstraction level, triggering in the mutual assistance process.

There have been several reviews of the UK police response. Her Majesty's Inspectorate of Constabulary and Fire and Rescue Service (HMICFRS) focused in their annual report on the initial response, positively commenting on how the police (despite significant reductions in people over the past 10 years) were embedded well in local resilience arrangements and had, in most cases, responded well to the need for new approaches required to support social distancing. ${ }^{17}$ Clements (2020) ${ }^{18}$ also reviewed the response of the UK police. They reviewed the PPE position and the national coordination and reported that forces had managed this well, providing enough PPE to equip staff.

The key learning from this review were positive feedback on the speed and organisation of the police response; the relationship between the state and the police using discretion; concerns about the wellbeing/fatigue of staff; and the ability of the UK Criminal Justice System to respond. More recently, the Police Federation of England and Wales (a staff association for constables, sergeants, and inspectors) surveyed their staff as part of an annual review of morale and wellbeing. The survey was carried out between July and September 2020, which is relevant as this was during the relative calm following the first peak and lockdown. Figure 3 shows the rise and fall in cases and, whilst there was concern about the virus, this was a period when government policy was to encourage people to re-engage fully in society. There were financial incentives to go back into restaurants and pubs, such as the 'Eat Out to Help Out' campaign, which reduced the costs of meals by up to $£ 10$. There was pressure on employees to return to the workplace and on schools, universities and colleges to open fully. The general 'mood' in government communications was that there is still some risk and a need to maintain social distancing, but this could be done safely if 'simple' rules were applied.

However, the government's scientific advisors were more cautious, but the 'needs of the economy' led to a message that suggested we should get back to near normal as soon as

Number of deaths registered by week, England and Wales, 28

December 2019 to 29 January 2021

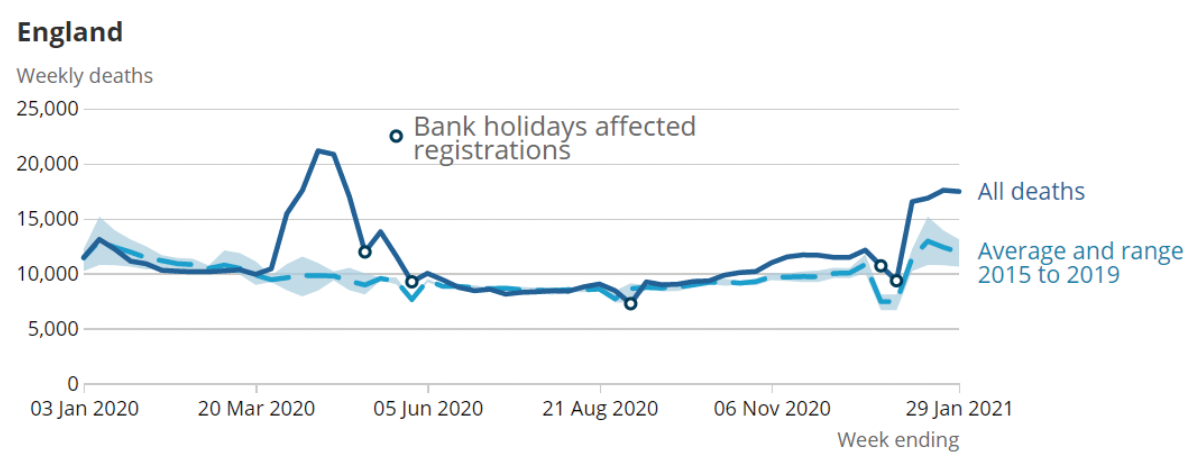

Figure 3 Deaths per week from the Office for National Statistics ${ }^{19}$ 
possible. Whilst the Police Federation survey was published in 2021 it relates to the experience of police officers in the first wave, and was carried out during a period when communications were of a reduced risk and confidence was increasing. Deaths amongst officers were exceedingly rare, and the early criticism of the police by politicians had dissolved. Within this background, the officers reported concerns that suggested that, whilst communication to them was good, more than $50 \%$ of those responding felt the more significant issues of equipment (PPE), testing and training were not sufficient (see Figure 4).

The survey also raises key issues on wellbeing. This is clearly a crisis on an unprecedented level, in which delivery of key services are dependent upon the frontline. Wider reviews on public sector services in the UK have identified concerns for wellbeing. Skills for Justice research showed that $68 \%$ of frontline staff in this wider sector felt a negative impact upon their mental health. ${ }^{21}$ The Federation review found staff were required to change their working arrangements, were often at risk of infection and unable to get leave. There have been many sad stories of officers taking their own life, or others being killed, as a direct result of COVID. There are others who have died from the virus and many who have changed their daily lives to reduce the risk to their families and loved ones. These are compounded by the impact from managing abstractions, illness and new roles. The Police Federation survey clearly exposes the scale of restrictions and change made to officers' and their families' daily lives (see Figure 5).

\begin{tabular}{|l|c|c|}
\hline To what extent do you agree or disagree with the following statements? & Disagree & Agree \\
\hline I have had access to adequate PPE when necessary during the COVID crisis & $34 \%$ & $48 \%$ \\
\hline I have had access to COVID antigen testing via my force & $42 \%$ & $31 \%$ \\
\hline I have had access to COVID antibody testing via my force & $62 \%$ & $14 \%$ \\
\hline My force has kept me up to date on COVID-related guidance & $8 \%$ & $78 \%$ \\
\hline I have received adequate training on the COVID crisis from my force & $30 \%$ & $41 \%$ \\
\hline
\end{tabular}

Figure 4 Proportion of respondents agreeing or disagreeing with statements related to the COVID-19 crisis $^{20}$

\begin{tabular}{|l|c|}
\hline As a result of the COVID crisis, have you experienced any of the following? & $53 \%$ \\
\hline I have had changes made to my usual duties or shifts & $29 \%$ \\
\hline I have had to take on additional duties or shifts & $27 \%$ \\
\hline I have needed to self-isolate at home & $25 \%$ \\
\hline I have been unable to book annual leave because of the pressures of work & $18 \%$ \\
\hline I have had my request for annual leave refused & $13 \%$ \\
\hline I have had my rest days cancelled & $8 \%$ \\
\hline I have had my annual leave cancelled & $7 \%$ \\
\hline I have needed to take special or dependents' leave & $7 \%$ \\
\hline I have needed to work from home as I am considered to be in a high-risk category & \\
\hline
\end{tabular}

Figure 5 Proportion of respondents experiencing changes to leave or duties during COVID 
Vol. 8, No. 1, 100-113.

\begin{tabular}{|l|c|c|}
\hline & Low Morale & High Morale \\
\hline Personal morale & $48 \%$ & $20 \%$ \\
\hline Force morale & $75 \%$ & $3 \%$ \\
\hline Police service morale & $85 \%$ & $1 \%$ \\
\hline
\end{tabular}

Figure 6 Proportion of respondents in 2020 reporting high or low morale

The pandemic has changed life for almost the whole population, but few other than the healthcare, social care, emergency responders, etc. have been in positions where they have been required to continue with their work in areas of risk and when their role has also been changed. There are many studies that have identified the impact of change, in particular the stress of unplanned and transactional changes to work, upon stress in the workplace. Such studies clearly link this with mental health and depression, the need for escape and feelings of helplessness ${ }^{22}$ - all significant risks to staff wellbeing.

The resultant risk to staff morale and safety is increased and, with this backdrop, it is surprising that the Police Federation survey reported the lowest score for low morale since annual surveys were increased. However, the picture for high morale continues to cause real concern, with only $1 \%$ thinking police service morale was high (see Figure 6).

Why might this be the case? Why is morale, if not getting higher, at least not as bad as it has been? In this circumstance the officers seem to be responding to a situation (or stimulus) and developing a coping response, which may relate to the emotions and rewards associated with their role. This mediated model suggests that some complex and important things are happening. However, the Police Federation survey indicates a high expected turnover $(10 \%)$ and high levels of disquiet over pay and conditions $(81 \%)$, and shows that $90 \%$ believe that how they are treated by the public has the largest impact on morale. Simply, officers are considering leaving, feel they are under paid (formally recognised) and say that public perception is extremely important.

In this circumstance, the change being applied organisationally is significant. New ways of delivering service, new roles and increased risks were introduced in a very short time. In addition, the pressure to remain at work and cope 'come what may', the sense of duty found amongst officers, and the inability to take leave to escape from the situation has significantly reduced the options to officers and their families in coping. At this time, perceptions of the police increased dramatically, with the ONS Crime survey recording $91 \%$ satisfaction in the public to the police response. ${ }^{23}$ In the Police Federation survey, $64 \%$ stated they were proud of what they did. It seems likely that the reduction in negativity is the reframing of the importance of their role and, even if the public are not happy, at least the officers are clear about the importance of their role.

These perceptions of positive regard may not come from all parts of society. This year has seen significant disorder and hatred of the police arising across the world. On the face of it, it seemed inconceivable that a political movement such as Black Lives Matter would find the traction to make a breakthrough across the world when the threat to life from the virus seemed so big. The circumstances of the death of Floyd George were, in themselves, extraordinary, but they were not unique. For many years, BAME suspects have been more likely to have force used against them by the police, not just in the US but in Europe, Australia and the UK too. Almost everywhere with diverse communities reports a similar dynamic, with identifiable minorities being subjected to greater use of force, incarceration and judicial penalty than the majority. 


\section{Policing the pandemic: Black Lives Matter}

In the US disparity in the use of force is is underlined by the greater use of lethal weapons and, therefore, the greater likelihood of that force leading to death. In the past 10 years more than 100 Black people have died at the hands of the police, making the risk twice that for white people. What is more chilling is the manner of those deaths. Many have occurred through shooting, but many also have involved positional asphyxiation, which is well documented and can easily be prevented - so easily that it becomes questionable that these events are simply coincidental. In 2014 Eric Forbs died whilst being restrained by police. His words, 'I can't breathe', were echoed by George Floyd 6 years later, with little seeming to have changed. ${ }^{24}$

The one aspect that has created a new dynamic is the growth of smart phones with recording and immediate publishing capabilities, with instances being regularly captured and circulated on social media. However, this alone does not explain the wave of demonstration and public outrage that followed the killing of George Floyd. There were several dynamics at play here which coalesced around this incident.

- The pandemic was high with concern about life and safety being felt universally. Then, in the US and UK, data was emerging showing people from BAME communities were more likely to die from the virus. ONS data showed BAME individuals had a 2.5 times greater risk to death in the UK. ${ }^{25}$ There seemed to be a reluctance from governments to accept this or be able to explain it, which seems to have destabilised belief in systems. Terror Management Theory suggests that we build a series of structures that enable us to manage the threat of death, but when these are shown to be inadequate our self-esteem and worth are affected. As the risks to life become exposed, people become less likely to accept the added risk of racially targeted and disproportionate use of force.

- The images were exceptionally clear. They showed what Black people already knew - that in times of restraint, officers' actions were not focused on the life of the person being arrested or questioned but were driven by other external events and fears. In this case to the point where they refused to hear the pleading for life.

- These events were systematic - it was not just an officer acting poorly, it resulted from training, from other officers' unwillingness to challenge and a perception that the officers had of being above the law.

- Acutely obvious was the overreaction to the threat posed by this individual. The perception of risk assessed as coming from the victims of police use of force suggested officers were making a stereotypical assessment and not treating each case as it developed. This specifically draws the debate into one of racism, as the threat perceived from Black people seems considerably higher than that from white.

- Finally, if people do not feel safe from the virus, they do not feel safe from crime and then they do not feel safe from the state, they will have increased concerns and perceptions of risk. When this is accentuated by seeing members of the majority elite being allowed to break the rules around the pandemic while their own community is disproportionately impacted by the use of police powers, there is a fear and energy ready to be directed towards a cause.

All of this was heightened by a government response that saw the police as 'doing their job', and failed to understand the concerns of local communities. Rather than responding to the issues being raised with thoughtful discussion, reflection and action, the political response was to abhor the protestors, send in paramilitary resources to 'maintain law and order' and to support those who created armed militia to patrol the streets. Local politicians (at state level) were labelled as weak and far left if they did not support the president's position, as he took a campaigning stance of law and order over resolution. 
Vol. 8, No. 1, 100-113.

In the UK, the response was more nuanced, with police focused on de-escalation and peaceful protest. However, this has not been without criticism. The Police and Crime Commissioner candidate for Bristol, Mark Shelford, was critical of the lack of action of police when they did not intervene when demonstrators damaged and removed a statue. ${ }^{26}$ Despite general recognition that by taking this stance the law was both enforced and violence averted, the narrative is one of weak police leadership. Attempting to force police action (take operational control), Shelford has set out his position that, whatever the cost, police should use force to achieve an outcome and maintain the status quo. Similar thoughts were expressed by the Home Secretary about the defacing of the Winston Churchill monument in Westminster. These attempts to undermine police leadership and ensure a more enforcement and power-driven model reflect the same desire to show who is in control and who has the power. These are not dynamics of liberal democracies; they pamper to those who are looking for simpler models of social control.

The disorder has abated but the problems have not. The over policing of areas of high diversity, driven by central agendas, and the under acceptance of the concerns of the use of force by the police (whether that is the use of lethal force or stop and search powers) are clear to see, as is the absence of a clear strategy to address them.

Policing structures in the UK are based upon the independence of the office of constable - the requirement that individuals take responsibility and are accountable for their own actions. The past 30 years of policy have been taking police into a more command and control approach, with officers' employees and with politicians driving activity. This has huge potential gain for politicians who, through control of the police, can direct things they want to claim and can blame others when they do not work. Professional police officers make decisions throughout their working day. These often have an immediate and long-term impact on individuals' lives. They do this by balancing the Human Rights of each person (not just those they label as criminal or bad) and, in so doing, are expected to have an ethical and value core that provides resilience and certainty. This requires strength of character and constant support in terms of standards and oversight. In other words, the highest form of leadership. When this fails, then the focus becomes clouded and the balance leads to compromises based upon personal power rather than the legitimate protection of the public.

In London, this has been against a backdrop of not only the pandemic but also a series of high-profile investigations and litigations involving BAME officers, many of senior rank. ${ }^{27}$ Rather than approaching these rare BAME senior police officers as assets, the organisation has allowed them to be bullied and unfairly criticised in the press. The result in the Metropolitan Police Service (over 30,0oo officers policing a diverse city) is:

- no female BAME officers above the rank of chief inspector;

- less than 1o BAME male officers above the rank of superintendent; and

- several high-profile employment tribunals and a stream of BAME officers with accounts of direct racism.

Failure to deal with these links directly back into the Black Lives Matter movement, as BAME officers often feel they are under attack in the workplace, are sometimes perceived as not representing their communities at home, do not have their incredible insights into the issues of diverse communities listened to, and they are under-valued. The same powerful response that wraps around the white officers who fail to protect those in their custody appears to be at play, restricting and holding back the careers of those who are working inside the organisations trying to bring about change. Despite the claims that institutional racism is an unhelpful label (one I made when serving and giving evidence to the Home Affairs Select Committee), the police need to accept that there is either racism, which as an institution they are failing to address, or the systems of leadership and management are not being applied fairly. Both smack of institutional racism, as defined by Macpherson, ${ }^{28}$ and both need to be addressed. 


\section{Policing the pandemic: conclusion}

This paper has covered a wide area of contemporary policing issues. The key dynamic throughout have been the application of power (through political controls), the issues of strain (pandemic and societal) and the police need for legitimacy. The principles of policing set out in 1829 have a clear and resonating theme - the police are the public and the public are the police, and any move away from this position leads to reductions in legitimacy and effectiveness, and an increase in the use of force. Throughout the paper, the drive from politicians to get closer to police, to use the power of the police to underline their popularist and political agendas, and the immensely challenging role officers perform have identified a series of fault lines in society. These will not diminish as the pandemic moves into a new phase and, as we saw in the last days of President Trump's administration, nor will the risk of spilling into violence and anti-democratic fever. The challenge for police leadership is defined by how society (and their forces) manage issues of fairness to reduce the amount of force and violence in society and ensure the state is there to protect all citizens.

\section{Notes}

${ }^{1}$ Rod Jarman is President of the London Policing College and Lead for Police Education and Research at the University of West London. Rod was in the Metropolitan Police Service for over 32 years and has developed a huge amount of experience in frontline policing, developing leadership and learning. He has achieved considerable success in policing, with a focus on neighbourhood policing, critical incident management, crime prevention, leadership and learning. rod.jarman@lonpolcol.co.uk

${ }^{2}$ Raven, B. H. (1992). A power/interaction model of interpersonal influence: French and Raven thirty years later. Journal of Social Behavior \& Personality, 7(2), 217-244. Accessed on 14/02/2021 from https://psycnet. apa.org/record/1993-01370-oo1.

3 Reference to Dominic Cummings' drive across England when ill to provide support to his family. See Coronavirus: How Dominic Cummings' trip to Durham damaged trust in the government | UK News | Sky News.

${ }^{4}$ Garland, D. (2002) The Culture of Control: Crime and Social Order in Contemporary Society. University of Chicago Press, US.

${ }^{5}$ Sky News (18th December 2020) Greater Manchester Police chief constable resigns after force placed into special measures: Manchester mayor Andy Burnham says the force has made 'an unacceptable lack of progress'. https://news.sky.com/story/greater-manchester-police-chief-constable-resigns-after-forceplaced-into-special-measures-12166616

${ }^{6}$ For instance, the call from UNICEF to take action - UNICEF calls for averting a lost generation as COVID19 threatens to cause irreversible harm to children's education, nutrition and well-being or that in UK press such as the standard on 25th January 2021 https://www.standard.co.uk/news/politics/boris-johnsonschools-reopen-easter-february-half-term-b9oog69.html

${ }^{7}$ BBC Reith Lectures 2020, BBC Radio 4 - The Reith Lectures, 2020: Mark Carney - How We Get What We Value, From Moral to Market Sentiments.

${ }^{8}$ Halford, E., Dixon, A., Farrell, G., Malleson, N. and Tilley, N. (2020) Crime and coronavirus: social distancing, lockdown, and the mobility elasticity of crime. Crime Science, 9(11). Accessed on 14/02/2021 from https://crimesciencejournal.biomedcentral.com/articles/10.1186/s40163-020-00121-w.

${ }_{9}^{9}$ Ross, H. (2020) Crime in England and Wales: year ending September 2020. Office for National Statistics. Accessed on 14/02/2021 from https://www.ons.gov.uk/peoplepopulationandcommunity/crimeandjustice/ bulletins/crimeinenglandandwales/yearendingseptember2020

${ }^{10}$ ONS (2021) Coronavirus and the latest indicators for the UKeconomy and society. Accessed 14/02/2021 from https://www.ons.gov.uk/peoplepopulationandcommunity/healthandsocialcare/conditionsanddiseases

${ }^{11}$ ONS (2021) Coronavirus (COVID-19) Infection Survey, UK: 12 February 2021 https://www.ons.gov.uk/ releases/coronaviruscovidiginfectionsurveyukıfebruary2021.

${ }^{12}$ Harcourt, B. (1998) Reflecting on the subject: a critique of the social influence conception of deterrence, the Broken Windows Theory, and order-maintenance policing New York style. Michigan Law Review, 97(2), 291-389. 
Vol. 8, No. 1, 100-113.

${ }^{13}$ Analysis from the Policing the Pandemic Conference held by the London Policing College with the International Police Association and University of West London.

${ }^{14}$ John Hopkins Coronavirus dashboard. Accessed from https://coronavirus-disasterresponse.hub.arcgis. com/datasets/bda759474ofd40299423467b48egecf6

${ }^{15}$ Analysis from the Policing the Pandemic Conference held by the London Policing College with the International Police Association and University of West London.

${ }^{16}$ See The Guardian, 'Peru: riot police block highway as people attempt to flee amid lockdown'. 2oth April 2020. Accessed on 14/02/2021 from https://www.theguardian.com/world/2020/apr/20/peru-riot-policehighway-teargas-coronavirus-lockdown

${ }^{17}$ Windsor, T. (2020) State of Policing: The Annual Assessment of Policing in England and Wales. HMICFRS London. Accessed on 14/02/2021 from https://www.justiceinspectorates.gov.uk/hmicfrs/publications/ state-of-policing-the-annual-assessment-of-policing-in-england-and-wales-2019/

${ }^{18}$ Clements, J. (2020) 'Policing the long crisis: an appraisal of the police response to COVID-19'. Accessed on 14/02/2021 from https://www.crestadvisory.com/post/policing-the-long-crisis-an-appraisal-of-thepolice-response-to-covid-19

${ }^{19}$ Office for National statistics, from deaths registered weekly in England and Wales, provisional. Accessed on 14/02/2021 from https://www.ons.gov.uk/peoplepopulationandcommunity/birthsdeathsandmarriages/ deaths/bulletins/deathsregisteredweeklyinenglandandwalesprovisional/weekending26february2021

${ }^{20}$ Chandler, N. (2021) Pay and Morale Survey 2020 - COVID-19 November 2020 Police Federation of England and Wales, UK. Accessed on 14/o2/2021 from https://www.polfed.org/media/16525/pay-and-morale-covidreport.pdf

${ }^{21}$ Enbank, S. (2020) COVID-19 Insights: Impact on Staff and Priorities for Recovery. Skills for Justice, UK. Accessed on 14/02/2021 from C19-WF-Report-impact-on-staff-and-organisational-priorities.pdf (sfjuk.com)

${ }^{22}$ Fugate, M., Kinicki, A. J. and Prussia, G. E. (2008). Employee coping with organizational change: an examination of alternative theoretical perspectives and models. Personnel Psychology, 61 (1), 1-36. Retrieved from http://ezproxy.uwl.ac.uk/login?url=https://www.proquest.com/scholarly-journals/employeecoping-with-organizational-change/docview/220138485/se-2?accountid=14769.

${ }_{23}$ Office for National statistics (ONS) (2020) Coronavirus and crime in England and Wales: August 2020. Accessed on 14/02/2021 from https://www.ons.gov.uk/peoplepopulationandcommunity/crimeandjustice/ bulletins/coronavirusandcrimeinenglandandwales/august2020

${ }^{24}$ Code Switch (2020) A Decade Of Watching Black People Die. Accessed on 14/02/2021 from https://www. npr.org/transcripts/865261916

${ }^{25}$ ONS (2021) Why have Black and South Asian people been hit hardest by COVID-19? Accessed on 14/02/2021 from https://www.ons.gov.uk/peoplepopulationandcommunity/healthandsocialcare/ conditionsanddiseases/articles/whyhaveblackandsouthasianpeoplebeenhithardestbycovid19/2020-12-14 ${ }^{26}$ Somerset County Gazette, 10th June 2020. PCC hopeful says Bristol statue protest was 'wanton, unlawful destruction'. Accessed on 14/02/2021 from PCC hopeful says Bristol statue protest was 'wanton, unlawful destruction' | Somerset County Gazette

${ }^{27}$ See the Home Affairs Select Committee for details - The Macpherson Report: twenty-one years on Committees - UK Parliament.

${ }^{28}$ Macpherson, W. (1999) The Stephen Lawrence Inquiry. HMSO, London, UK. 